\title{
THE COST OF KIDNEY TRANSPLANTATION AT THE MERKUR UNIVERSITY HOSPITAL, ZAGREB, CROATIA
}

\author{
Ivan Neretljak ${ }^{1}$, Mario Sučić ${ }^{1}$, Branislav Kocman ${ }^{2}$ and Mladen Knotek ${ }^{3}$ \\ ${ }^{1}$ Department of Urology, Merkur University Hospital, Zagreb, Croatia; \\ ${ }^{2}$ Department of Surgery, Merkur University Hospital, Zagreb, Croatia; \\ ${ }^{3}$ Department of Nephrology, University Hospital Crosshouse, Kiemarnock, UK
}

\begin{abstract}
SUMMARY - The aim was to determine the cost of hospitalization for a transplant procedure and identify the independent variables associated with the cost of transplantation. The investigation was designed as a retrospective single-center cohort study conducted at a tertiary university hospital transplant center in Zagreb, Croatia. The study included 219 consecutive kidney recipients transplanted during the 2007-2013 period at the Merkur University Hospital. There were 141 male and 78 female patients having undergone kidney transplantation during the study period. The majority of kidney transplants were from a deceased donor $(n=179)$, while 40 were from a living donor. The mean cost of a transplantation was $86,140 \pm 42,240 \mathrm{HRK}(11,460 \pm 5,600 €)$, ranging from 29,000 HRK $(3,860 €)$ to $408,000 \mathrm{HRK}(54,000 €)$. In the bivariate analysis, the variables associated with the cost of transplantation were the length of hospital stay, delayed graft function, death of the patient, graft loss, use of steroids, and death-censored graft loss. In the multivariate analysis, delayed graft function was the only statistically significant variable for the cost of transplantation. Since only delayed graft function had an impact on the cost of transplantation in this study, certain steps such as shortening of the cold ischemia time (better organization of organ transport), better education of family members for living donors, and higher percentage of patients on peritoneal dialysis should be taken to lower the percentage of delayed graft function.
\end{abstract}

Key words: Kidney transplantation; Delayed graft function; Hospital cost; Peritoneal dialysis; Cold ischemia time

\section{Introduction}

Kidney transplantation (KT) is the best form of treatment for end-stage renal disease (ESRD) ${ }^{1,2}$. Despite the fact that the program for pre-emptive kidney transplantation exists, dialysis is the first treatment for ESRD for most patients. When compared to dialysis, $\mathrm{KT}$ is initially the more expensive modality for renal replacement therapy. But the cost evens out after the first year, after which transplantation becomes a cheaper option $^{2-4}$.

Correspondence to: Ivan Neretljak, MD, Department of Urology, Merkur University Hospital, Zajčeva 19, HR-Zagreb, Croatia

E-mail: ineretljak@gmail.com

Received December 31, 2019, accepted July 22, 2020
Around $0.1 \%$ of the European population are on some form of renal replacement therapy. Although this is a small percentage, it accounts for about $2 \%$ of all healthcare funds. Thus, the ESRD treatment costs are high and they represent a major burden for the health system, even in highly developed countries ${ }^{5,6}$.

In Croatia, the cost of dialysis and KT is covered by the general public health insurance. Therefore, renal replacement therapy is free for patients. The reimbursement fee for dialysis and KT is determined by the Croatian Health Insurance Fund. The fee for one incenter hemodialysis (HD) session is around $950 \mathrm{HRK}$ $(126 €)$, for continuous ambulatory peritoneal dialysis 300 HRK (40€), and for assisted peritoneal dialysis per procedure 310-500 HRK (41-66 €). The fee for 
KT, based on the Diagnostic Therapy System is 63,900 HRK $(8,520 €)$ for a transplantation without complications and 106,650 HRK (14,133 €) for a transplantation with complications.

Therefore, the aim of this study was to determine the material cost of hospitalization for a transplant procedure and to identify independent variables associated with the cost of transplantation.

\section{Materials and Methods}

Initially, 229 consecutive kidney recipients, transplanted at the Merkur University Hospital, Zagreb, Croatia during the 2007-2013 period were screened for inclusion in this retrospective cohort study. Upon exclusion of preemptive kidney transplants, 219 deceased donor or living donor kidneys remained. The study was approved by the Merkur University Hospital Ethics Committee and was performed in accordance with the Helsinki Declaration. As it was a retrospective study, no formal patient consent was required. However, all patients gave informed consent for research use of their clinical data at the time of hospitalization.

Donor kidney was placed in the iliac fossa using the extraperitoneal approach by Gibson incision. Urinary catheter was placed in all patients just before the operation. All patients had a J-J ureteral stent placed for one month, post-transplant. A drain was placed in all patients for several days. In peritoneal dialysis (PD) patients, peritoneal catheter was removed during the transplant operation. If renal replacement therapy was necessary after the transplantation, hemodialysis was performed via a central venous catheter in ex-PD patients. All patients received triple or quadruple immunosuppressive therapy (daclizumab or anti-thymocyte globulin, calcineurin inhibitor (cyclosporine or tacrolimus), mycophenolate mofetil, with or without maintenance corticosteroids). After the transplantation, all patients received prophylactic therapy with sulfamethoxazole and trimethoprim $960 \mathrm{mg}$ daily (adjusted for renal function), fluconazole $10 \mathrm{mg}$ qid and valganciclovir hydrochloride $900 \mathrm{mg}$ daily (adjusted for renal function) for at least three months after the transplantation.

Delayed graft function (DGF) was defined as the use of dialysis within seven days of the transplantation. The patients with DGF stayed at the hospital until they became dialysis-free.
The cost of transplantation was calculated by adding up the cost of surgery (material) and the cost of drugs during the period of hospitalization required for the transplantation procedure.

\section{Statistics}

Statistical analysis was performed using Statistica for Windows version 13 (TIBCO, Tulsa, OK, USA). Numerical values were expressed as mean \pm standard deviation or median (interquartile range, QR), as appropriate. Survival was calculated using the KaplanMeier test, with comparison of survival curves using the log-rank test. The proportions were compared with the $\chi^{2}$-test. The independent association of individual variables with the dialysis modality before transplantation was analyzed using multivariate linear regression with inclusion of the variables associated with the dialysis modality before transplantation in univariate analysis, where $p \leq 0.1$. The level of statistical significance was set at $\mathrm{p}<0.05$.

\section{Results}

This study included 219 patients (141 males and 78 females) who received a KT between 2007 and 2013 at our hospital. The majority of kidney transplants were from a deceased donor $(n=179)$, whereas 40 were from a living donor. Prior to transplantation, 172 patients were on $\mathrm{HD}$ and 47 were on PD. The mean patient age was $49.9 \pm 12.1$ years and the mean donor age was $49.8 \pm 12.1$ years. The overall dialysis vintage was $50.4 \pm$ 49.4 months. The dialysis vintage was $35.1 \pm 28.5 /$ $50.4 \pm 49.4$ months for patients who were on $\mathrm{PD} / \mathrm{HD}$ before transplantation $(\mathrm{p}<0.01)$ (Table 1). The DGF incidence in this study was $45 \%$. The DGF incidence

\section{Table 1. Descriptive statistics}

\begin{tabular}{|l|l|l|}
\hline & Mean & Std. Dev. \\
\hline Recipient age (years) & 49.9 & 12.1 \\
Dialysis vintage (months) & 50.4 & 49.4 \\
Recipient BMI & 25.7 & 4.5 \\
Donor age (years) & 49.6 & 12.1 \\
Donor BMI & 26.4 & 4.2 \\
$\begin{array}{l}\text { Hospital stay after } \\
\text { transplantation (days) }\end{array}$ & 19.5 & 12.4 \\
\hline
\end{tabular}

$\mathrm{BMI}=$ body mass index 
Table 2. Bivariate analysis of variables related to the cost of transplantation

\begin{tabular}{|l|l|l|}
\hline & \multicolumn{2}{|l|}{ Cost of transplantation } \\
\hline & $\begin{array}{l}\text { Spearman } \\
\text { correlation }\end{array}$ & $\mathrm{p}$ value \\
\hline Recipient age (years) & 0.053 & 0.441 \\
Recipient BMI & 0.077 & 0.259 \\
Hospital stay (days) & 0.403 & 0.000 \\
Dialysis vintage (months) & 0.066 & 0.338 \\
Donor age (years) & 0.109 & 0.107 \\
Donor BMI & 0.069 & 0.323 \\
\hline
\end{tabular}

$\mathrm{BMI}=$ body mass index was statistically lower in patients who had been on PD before transplantation $(\mathrm{p}<0.01)$.

The mean cost of transplantation was $86,140 \pm 42,240$ HRK $(11,460 \pm 5,600 €)$, ranging from 29,000 HRK $(3,860 €)$ to $408,000 \mathrm{HRK}(54,000 €)$. In the bivariate analysis, the variables associated with the cost of transplantation were the length of hospital stay, DGF, death of the patient, graft loss, use of steroids, and deathcensored graft loss (Tables 2 and 3).

Multivariate analysis was subsequently performed to identify independent variables associated with the cost of transplantation (Table 4). All independent variables included in the multivariate analysis were

Table 3. Bivariate analysis of the variables related to the cost of transplantation

\begin{tabular}{|c|c|c|c|c|}
\hline & \multicolumn{3}{|c|}{ Cost of transplantation in thousands of HRK and $€$} \\
\hline & & Mean value & Std. Dev. & $\mathrm{p}$ value \\
\hline \multirow[t]{2}{*}{ Gender } & Male $(n=141)$ & $85,657(11,420)$ & $31,462(4,194)$ & 0.124 \\
\hline & Female $(\mathrm{n}=78)$ & $87,026(11,603)$ & $57,082(7,610)$ & \\
\hline \multirow[t]{2}{*}{ Type of dialysis } & $\mathrm{PD}(\mathrm{n}=47)$ & $82,702(11,026)$ & $31,681(4,224)$ & 0.596 \\
\hline & $\operatorname{HD}(\mathrm{n}=172)$ & $87,094(11,612)$ & $44,751(5,966)$ & \\
\hline \multirow[t]{2}{*}{ Donor } & Deceased $(n=173)$ & $85,548(11,406)$ & $43,399(5,786)$ & 0.342 \\
\hline & Living $(n=46)$ & $88,775(11,836)$ & $37,038(4,938)$ & \\
\hline \multirow[t]{2}{*}{ Steroids } & $Y(n=166)$ & $91,028(12,137)$ & $47,104(6,280)$ & 0.004 \\
\hline & $N(n=53)$ & $76,702(10,226)$ & $28,728(3,830)$ & \\
\hline \multirow[t]{2}{*}{ DGF } & $Y(n=91)$ & $98,153(13,087)$ & $53,594(7,145)$ & 0.000 \\
\hline & $N(n=128)$ & $76,252(10,166)$ & $26,189(3,491)$ & \\
\hline \multirow[t]{2}{*}{ Death of patient } & $Y(n=20)$ & $104,323(13,909)$ & $44,536(5,938)$ & 0.001 \\
\hline & $N(n=199)$ & $82,765(11,035)$ & $41,040(5,472)$ & \\
\hline \multirow[t]{2}{*}{ Graft loss } & $Y(n=22)$ & $101,857(13,580)$ & $41,071(5,476)$ & 0.000 \\
\hline & $N(n=197)$ & $82,371(10,982)$ & $41,751(5,566)$ & \\
\hline \multirow[t]{2}{*}{ Death censored graft loss } & $Y(n=6)$ & $115,583(15,411)$ & $56,250(7,500)$ & 0.003 \\
\hline & $N(n=213)$ & $84,419(11,255)$ & $40,795(5,439)$ & \\
\hline
\end{tabular}

DGF $=$ delayed graft function $; \mathrm{PD}=$ peritoneal dialysis $\mathrm{HD}=$ hemodialysis $; \mathrm{N}=$ no; $\mathrm{Y}=$ yes

Table 4. Multivariate linear regression

\begin{tabular}{|l|l|l|l|}
\hline Model & Beta & Std. Error & $\mathrm{p}$ value \\
\hline DGF & 0.202 & 6.503 & 0.001 \\
Death of patient & 0.086 & 16.240 & 0.054 \\
Steroids & 0.048 & 6.719 & 0.523 \\
$\begin{array}{l}\text { Death censored } \\
\text { graft loss }\end{array}$ & 0.522 & 14.917 & 0.709 \\
\hline
\end{tabular}

DGF $=$ delayed graft function statistically significant in the bivariate analysis. Considering the high correlation of DGF with the length of hospital stay and the high correlation of overall graft loss with death of the patient, we only included DGF and death of the patient in the multivariate analysis. Thus, a multivariate linear regression model consisted of DGF, patient death and use of steroids, and death-censored graft loss as the potential independent variables, with the cost of hospital stay during 
transplantation as a dependent variable. After analysis, only DGF remained a statistically significant variable associated with the cost of transplantation, with patient death being borderline significant.

\section{Discussion}

This retrospective cohort study included 219 kidney recipients, transplanted during the 2007-2013 period at a tertiary hospital in Zagreb, Croatia. The mean cost of kidney transplantation during the first hospitalization in our center was $86,140 \operatorname{HRK}(11,485 €)$. This number is similar to a French single-center study that estimated the cost of hospital stay for kidney transplantation to be $14000 €^{7}$. The cost of KT differs from country to country. In Sweden, the cost for the first 3 years after KT is 44,000 to $68,000 €^{8}$. In Germany, the cost is $34,000 €$ of the first post-transplant year and 14,000 € of the second post-transplant year'. In Belgium, the cost of the first post-transplant year is $40,000 €^{10}$.

Unfortunately, we could not calculate the cost of transplantation throughout the first year. The reason is that the patients had their visits at our center but all medications and some diagnostic procedures were provided by their primary care physicians. It was one of the drawbacks of the study. Another drawback was its design as a retrospective, single-center, single-country study, with a relatively small number of patients included.

The mean cost of dialysis in Croatia (without medication) is $100,000-140,00 \mathrm{HRK}(13,333-18,666 €)$ per year. The cost of dialysis differs from country to country. In Spain, the mean cost of dialysis is $37,000 €$ for $\mathrm{HD}$ and 25,000 $€$ for PD patients ${ }^{11}$. In Germany, total dialysis related cost is $54,777 €$ per year ${ }^{12}$.

Depending on the type of dialysis, one can assume that the cost of transplantation at the Merkur University Hospital is greater than the cost of dialysis during the first year. After the first post-transplant year, KT is more cost-effective than dialysis. This is in accordance with other studies ${ }^{1,13}$.

In the multivariate analysis, only DGF was a statistically significant variable for the cost of transplantation. The incidence of DGF varies in different studies from $15 \%$ to $30 \%{ }^{14}$. Such a big difference can be ascribed to different definitions of DGF, as well as to different donor and recipient characteristics in differ- ent centers. The most common definition that we used as well, is the use of dialysis within seven days of the transplantation. In this study, $45 \%$ of the patients had DGF. When compared with some other studies ${ }^{15}$, it was a very high percentage. We can only speculate that some of the reasons for this high DGF incidence may be the high prevalence of highly immunized patients, or patients with significant vascular comorbidities who received a transplant in our center. According to most studies, the risk factors for DGF are cold ischemia time, donor age, and type of donor ${ }^{16-18}$. Similarly, cold ischemia time and type of donor ( $\mathrm{p}=0.000$ both) were the risk factors for DGF in our study. Although some authors concluded that there was no association between the pre-transplant dialysis modality and $\mathrm{DGF}^{19}$, we found that the pre-transplant treatment with PD was associated with a lower frequency of DGF. Similar results have been reported by Van Biesen et al..$^{20}$, Snyder et al. ${ }^{21}$, and Freitas et al..$^{22}$. The reasons for lower rates of DGF in patients on PD before transplantation are not clear, but may include better preserved residual native kidney function and some over-hydration just prior to the transplantation procedure.

\section{Conclusion}

Since only DGF had an impact on the cost of transplantation in this study, certain steps such as shortening of the cold ischemia time (better organization of organ transportation), better education of family members for living donors, and higher percentage of patients on PD (in Croatia only 5.7\% patients are on PD) should be taken to lower the percentage of DGF.

\section{References}

1. Kaló Z, Járay J, Nagy J. Economic evaluation of kidney transplantation versus hemodialysis in patients with end-stage renal disease in Hungary. Prog Transplant. 2001;11(3):188-93. DOI: 10.7182/prtr.11.3.c065760410446707

2. Sesso R, Eisenberg JM, Stabile C, Draibe S, Ajzen H, Ramos O. Cost-effectiveness analysis of the treatment of end-stage renal disease in Brazil. Int J Technol Assess Health Care. 1990;6(1):107-14. DOI: 10.1017/s0266462300008965

3. Laupacis Keown P, Pus N, Krueger H, Ferguson B, Wong C, Muirhead N. A study of the quality of life and cost-utility of renal transplantation. Kidney Int. 1996;50(1):235-42. DOI: 10.1038/ki.1996.307 
4. Salonen T, Reina T, Oksa H. Cost analysis of renal replacement therapies in Finland. Am J Kidney Dis. 2003;42(6):1228-38. DOI: $10.1053 /$ j.ajkd.2003.08.024

5. Vanholder R, Davenport A, Hannedouche T, Kooman J, Kribben A, Lameire N, et al. Reimbursement of dialysis: a comparison of seven countries. J Am Soc Nephrol. 2012;23:1291-8. DOI: 10.1681/ASN.2011111094

6. Dor A, Pauly MV, Eichleay MA. End-stage renal disease and economic incentives: the International Study of Health Care Organization and Financing (ISHCOF). Int J Health Care Finance Econ. 2007;7:73-111. DOI: 10.1007/s10754-007-9024-9

7. Chaumard N, Fagnoni P, Nerich V, Limat S, Dussaucy A, Chalopin JM, Bittard H, Woronoff-Lemsi MC. Hospital costs of renal transplant management. Transplant Proc. 2008 Dec;40 (10):3440-4. DOI: 10.1016/j.transproceed.2008.03.177

8. Chamberlain G, Baboolal K, Bennett H, Pockett RD, McEwan P, Sabater J, Sennfält K. The economic burden of posttransplant events in renal transplant recipients in Europe. Transplantation. 2014 Apr 27;97(8):854-61. DOI: 10.1097/01. TP.0000438205.04348.69

9. Hagenmeyer EG, Häussler B, Hempel E, Grannas G, Kaló Z, Kilburg A, Nashan B. Resource use and treatment costs after kidney transplantation: impact of demographic factors, comorbidities, and complications. Transplantation. 2004 May 27;77(10):1545-50. DOI: 10.1097/01.tp.0000121763.44137.fa

10. Chaib-Eddour D, Chaib-Eddour H, Malaise J, Mourad M, Squifflet JP. Cost of renal transplant in Belgium. Transplant Proc. 2005 Jul-Aug;37(6):2819-20. DOI: 10.1016/j.transproceed.2005.05.035

11. Villa G, Rodríguez-Carmona A, Fernández-Ortiz L, Cuervo J, Rebollo P, Otero A, Arrieta J. Cost analysis of the Spanish renal replacement therapy programme. Nephrol Dial Transplant. 2011 Nov;26(11):3709-14. DOI: 10.1093/ndt/gfr088

12. Icks A, Haastert B, Gandjour A, Chernyak N, Rathmann W, Giani $G$, et al. Costs of dialysis - a regional population-based analysis Nephrol Dial Transplant. 2010 May;25(5):1647-52. DOI:10.1093/ndt/gfp672

13. Rui Fu, Nigar Sekercioglu, Whitney Berta, Peter C. Coyte. Cost-effectiveness of deceased-donor renal transplant versus dialysis to treat end-stage renal disease: a systematic review. Transplant Direct. 2020 Feb;6(2):e522. DOI: 10.1097/TXD. 0000000000000974
14. Irish WD, Ilsley JN, Schnitzler MA, Feng S, Brennan DC. A risk prediction model for delayed graft function in the current era of deceased donor renal transplantation. Am J Transplant. 2010; 10(10):2279-86. DOI: 10.1111/j.1600-6143.2010.03179.x

15. Tapiawala SN, Tinckam KJ, Cardella CJ, Schiff J, Cattran DC, Cole EH, et al. Delayed graft function and the risk for death with a functioning graft.J Am Soc Nephrol.2010 Jan;21(1):15361. DOI: 10.1681/ASN.2009040412

16. McLaren AJ, Jassem W, Gray DW, Fuggle SV, Welsh KI, Morris PJ. Delayed graft function: risk factors and the relative effects of early function and acute rejection on long-term survival in cadaveric renal transplantation. Clin Transplant. 1999;13(3):266-72.DOI: 10.1034/j.1399-0012.1999.130308.x

17. Koning $\mathrm{OH}$, Ploeg RJ, van Bockel JH, Groenewegen M, van der Woude FJ, Persijn GG, et al. Risk factors for delayed graft function in cadaveric kidney transplantation: a prospective study of renal function and graft survival after preservation with University of Wisconsin solution in multi-organ donors. European Multicenter Study Group. Transplantation. 1997;15; 63(11):1620-8. DOI: 10.1097/00007890-199706150-00015

18. Irish WD, McCollum DA, Tesi RJ, Owen AB, Brennan DC, Bailly JE, Schnitzler MA. Nomogram for predicting the likelihood of delayed graft function in adult cadaveric renal transplant recipients. J Am Soc Nephrol. 2003;14(11):2967-74. DOI: 10.1097/01.ASN.0000093254.31868.85

19. Yang Q, Zhao S, Chen W, Mao H, Huang F, Zheng Z, et al. Influence of dialysis modality on renal transplant complications and outcomes. Clin Nephrol. 2009;72(1):62-8. DOI: 10.5414/cnp72062

20. Van Biesen W, Vanholder R, Van Loo A, Van Der Vennet M, Lameire N. Peritoneal dialysis favorably influences early graft function after renal transplantation compared to hemodialysis. Transplantation. 2000;69(4):508-14. DOI:10.1097/00007890200002270-00008

21. Snyder JJ, Kasiske BL, Gilbertson DT, Van Der Vennet M, Lamerie NA. A comparison of transplant outcomes in peritoneal and hemodialysis patients. Kidney Int. 2002;62(4): 1423-30. DOI: 10.1111/j.1523-1755.2002.kid563.x

22. Freitas C, Fructuoso M, Martins LS, Almeida M, Pedroso S, Dias L, et al. Posttransplant outcomes of peritoneal dialysis versus hemodialysis patients. Transplant Proc. 2011;43(1): 113-6. DOI: $10.1016 /$ j.transproceed.2010.12.008 
Sažetak

\section{TROŠKOVI TRANSPLANTACIJE BUBREGA U KLINIČKOJ BOLNICI MERKUR, ZAGREB}

\section{Neretljak, M. Sučic, B. Kocman i M. Knotek}

Cilj istraživanja bio je odrediti troškove hospitalizacije za postupak presađivanja bubrega i identificirati nezavisne varijable povezane s troškovima transplantacije. Istraživanje je provedeno kao retrospektivna kohortna studija u jednom kliničkom centru. Studija je obuhvatila 219 uzastopnih transplantacija bubrega u razdoblju od 2007. do 2013. godine u Kliničkoj bolnici Merkur, odnosno 219 bolesnika (141 muškaraca i 78 žena). Većina transplantiranih bubrega je bila od preminulog ( $\mathrm{n}=179)$ donora, dok ih je 40 bilo od živog davatelja. Prosječni trošak transplantacije iznosio je 86.140 42.240 HRK $(11.460 \pm 5.600 €)$. U bivarijatnoj analizi varijable povezane s cijenom transplantacije bile su trajanje hospitalizacije, odgođena funkcija presatka, smrt bolesnika, gubitak presatka, upotreba steroida i cenzurirani gubitak presatka. U multivarijatnoj analizi samo je odgođena funkcija presatka bila statistički značajna varijabla za troškove transplantacije. Budući da je samo odgodena funkcija presatka u ovom istraživanju utjecala na troškove transplantacije, potrebno je poduzeti određene korake kao što su skraćivanje vremena hladne ishemije (bolja organizacija transporta organa), bolje obrazovanje članova obitelji za žive donore i veći postotak bolesnika na peritonejskoj dijalizi kako bi se smanjila incidencija odgođene funkcije presatka.

Ključne riječi: Transplantacija bubrega; Odgođena funkcija presatka; Bolnički troškovi; Peritonejska dijaliza; Trajanje bladne ishemije 